\title{
Revitalization of Oral Literature Tradition of Balinese Society Based Character Values As Deradicalism Effort
}

I Made Suarta ${ }^{\text {a }}$

Article history: Received 20 June 2017; Accepted in revised form 5 November 2017; Approved 12 November 2017; Available online 1 December 2017

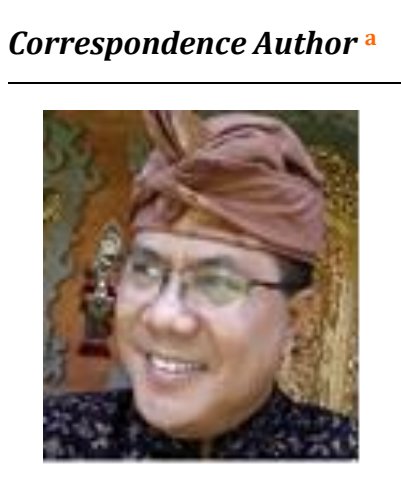

Keywords

Balinese literature;

Deradicalism;

Oral literature;

radicalism seeds;

Revitalization;
Abstract

The present study was to discuss the importance of revitalizing Balinese literature towards the children from an early age as an alternative against the radicalism seeds. Indonesian currently has a very serious problem, one of them was the growing understanding of radicalism that has a potential to threaten the sovereignty of the nation and the state of Indonesia. The radicalism idea must be soon opposed to the noble values contained in the oral literary tradition. On the early inculcation of the oral literary tradition for children, it could affect psychology and characterize the child who was oriented towards the noble values of culture in which the oral literature was born. Regarding the growth of children's awareness of the noble values of culture consist of in an oral literature, unlike the ethical and religious teachings, the inclusion chances of radicalism for the children were very small. Therefore, the lofty values of the oral literary tradition were defensive and attack. It defined defense on the radicalism onslaught and attack behind the radicalism idea.

e-ISSN : 2550-7001, $p$-ISSN : 2550-701X@ Copyright 2017. The Author. SS Journals Published by Universidad Técnica de Manabí. This is an open-access article under the CC BY-SA 4.0 license (https://creativecommons.org/licenses/by-sa/4.0/) All rights reserved.

\section{Contents}

Abstract

1. Introduction

2. Research Method

a Indonesian and Local Language Studies Program, IKIP PGRI Bali-Indonesia 


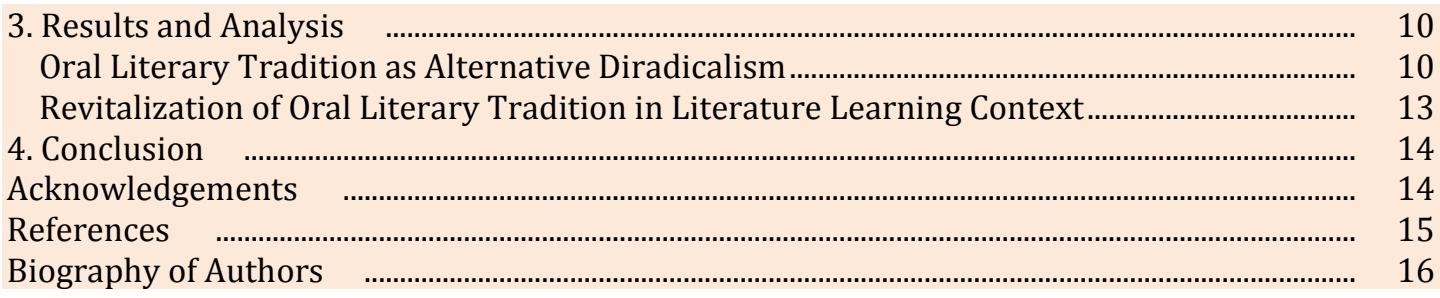

\section{Introduction}

The serious problem faced by Indonesian currently is the humanitarian crisis. The humanitarian crisis that is meant is an honest human crisis/integrity, moral, ethical, and noble. This nation still covered issues unlike corruption, sexual crimes, vandalism, mass fights, practical political life, and even the most serious problem is the acts of intolerance and radicalism leading to the disintegration of the nation. Moreover, regarding the globalization, modernization, and the puritanism strictness is feared can lead to erosion of the homeland loves. It never gets pay attention, this kind of problem must be taken seriously due if it ignored, will be fatal for the nation and state sustainability of the unity of the Indonesian Republic.

Radicalism is an understanding that oriented all actions kinds on the principles of the political violence to make changes or renewal of the social and state. Terror, extremism, and anarchism are parts of the radicalism type that must be neutralized. If it is related to the noble values of Pancasila with the motto of Bhinneka Tunggal Ika. It is stated that radicalism is not in accordance with the personality of the Indonesian nation. Radicalism and Pancasila are two contradictory particles, unlike water and fire that can not be united. Therefore, for the sustainability of the Indonesian nation existence, the seeds of radicalism in every life joint of nation and state must be eliminated in this archipelago to realize the national stability.

An effort that can be conducted to neutralize the early seeds of radicalism is to revitalize the oral literature tradition as a nation's cultural heritage. An oral literature tradition is a form of the material expression of the human experience and the representation of noble social and cultural values that consist of universal truths of the human nature. Oral tradition is any form of inheritance of the customs born of a social group delivered or passed on orally to each generation. Every tradition must have the content of values, meaning, and function for society. A tradition is customary binding to its supporting society, a tradition can also be stated to reflect the life and way of looking at the habits of a social group. Oral literature can include prose and oral poetry in the carry out of the spoken language and still use the local language. Oral literature function as a literary work is dulce et utile. Sudjiman (1995: 15) stated that:

"The many oral literature are educating of the moral guidance, exemplary, life wisdom, i.e. social and religious life. Another characteristic of the oral literature is entertaining it. There is the sound of rhyming sound, the regularity of rhyme, and the style of language and figure of speech. In its presentation, the many oral literatures are enthralling, soothing to feelings, and giving rise to a sense of beauty that unhappy issues life are forgotten for a moment."

Regarding the ethno-ideology perspective of the oral literature is able to instill awareness about the understanding, appreciation, and practice of the ideological values of Indonesian culture and nation. In the oral literature consist of harmony and aesthetics that can be used as a guide for the children formation who love the character of local wisdom as the identity of the Indonesian nation. An oral literature is born and developed based on the motivation, creations, and ideas of the creator in transforming ethical, moral, and religious values and norms to the people. Oral literary tradition can be used as a medium of enlightenment of human life values

Suarta, I. M. (2017). Revitalization of oral literature tradition of Balinese society based character values as deradicalism effort. International Journal of Social Sciences and Humanities, 1(3), 8-16. https://doi.org/10.29332/ijssh.v1n3.48 
that are usually used as a guide, both speaking and acting in accordance with the norms prevailing in the society.

The humanization process through the oral literary tradition of children should take precedence to reach children character, civilized, dignified, and love to the homeland. Humanization through the oral literature tradition is seen as a process of the character formation that views the human, unlike essentially an ethical and human being. Mangunwijaya (in Tilaar, 2000: 189) stated that humanization is not just a life but to manifest existence that is the human must coexist as the God creature. Oral literary tradition guides the child's behavioral process to vertical or horizontal life values. Here is the role of the environment, among family, school, and social to revitalize the noble oral literature tradition in life as the basis of education to produce the children's culture.

Oral literature is part of a cultural richness whose existence is heavily dependent on the society to its supporters. The oral literature development currently is very apprehensive. The oral literature pulse seems to weaken, even this tradition may become extinct. The globalization influence is one of the things that cause the cultural values displacement, either in the form of association that stems from the society thinking itself and from outside society so that the oral literature shift began to appear. This is in accordance with the view by Moehanto (1987) which stated that oral literature is a form of cultural tradition that is communal, where it is born, lived, and developed by the society, its development and tidal also follow the dynamics that occur in the society.

In the family environment, it is very rare for parents to tell stories to their children. They are too busy on working and career due to the influence of a consumptive global culture. In fact, telling the story to children has a role in developing cognitive, effective, and psychomotor aspect. In addition, it can also develop a personality their self and social, so as to refine the soul and personal child. Widodo (2013: 20-21) stated that literature serves not only as an educational agent, the forming of the innocent human beings, but also forming the souls of nationalism love in their homeland.

Revitalizing oral literature in the social life is very important as an alternative toward off the candidate of radicalism in the children. Building the child character through the oral literature tradition should be applied early or commonly called psychologists as a golden age, due this age is proven to determine the children ability in developing their potential. Freud (in Tilaar, 2000) stated that a qualified character must be established from an early age, failure in good personality cultivation at an early age will form troubled individuals in adulthood. If the child succeeds in inheriting meaningful personality values at an early age, then their adult will be a more meaningful person to others.

\section{Research Method}

The present study is a qualitative research. The data is collected by purposive sampling as well as the interview for specific purposes. It is explored based on the paraphrase regarding the descriptive analysis.

\section{Results and Analysis}

\section{Oral Literary Tradition as Alternative Deradicalism}

In the globalization and modernization context has gotten a change in the human life basis. On the one hand, to be a positive impact but not least become negative. An instant life allows the children to easily access a violent content therefore, it can influence their thinking and development. This symptom is actually very worrying if it is not addressed may be the nature of radicalism entered and developed in the child's personality. On the other hand, the protection weakness, the family fading, and the school environment figures lead to easy socialization radicalism and a place in their minds to fill their trust vacuum. This is further exacerbated by the active role of the family in guiding and instilling moral values as it shrinks. The parents are focused on their work and career so that the children get caught up in the digital world. Consciously or not, the parent role is now beginning to be replaced by digital 
tools. The child mindset becomes easily influenced and rapidly hypnotized in the digital world, therefore, the child tends to be impulsive, individualistic, and the riskiest is contaminated with the radicalism thought.

Revitalizing of the oral literature tradition in the child life is a necessity to respond radically to dialogue and absorption. It is the family and the school environment can also be stated as the efforts to prevent the radicalism basis through a cultural approach. Through, the oral literature revitalization means that it has strengthened the traditional roots and the built hegemony to resist the violent nature that is reflected in radicalism. An early inculcation of the oral literary traditions to the children can weaken the radicalism energy and indirectly revive the local traditions that have a wealth of the local wisdom values. The value content of the oral literary tradition in the child will not only be defensive towards the radicalism onslaught, but also the attack towards the radicalism. That is due to the teachings and the local wisdom values in oral literature are two things that are very contrary to the violent nature that characterizes radicalism. Therefore, if the two different are met, there will be an intersection between them.

Revitalizing of the oral literature tradition in a life, the family and educational institutions are the most realistic and strategic action taken to keep the children from the radicalism influence. In an ethnically ideological context, it offers the lofty values of the local wisdom ethnic. An oral literary tradition is an expression of the ethnic cultural emotion and representation. Through the tradition of the oral literature, the one wishes to convey ideas concerning the reality of the life framed by imperative fictitious nuances. Whereas, in the philosophical context, the oral literature tradition is seen as a representation of the human creativity, feeling, and initiation which can be seen from three perspectives, i.e. (1) An oral literature is a series of the human life and existence, (2) the media for the human to find teak self and the life essence, and (3) the ethical teaching of the human (Moehanto, 1987). An oral literary tradition based on the philosophical perspective can be represented as knowledge or education in the form of letters/suggestions/"pitutur/advisement" for the child to live in harmony and coexist in the society (Kattsof, 2004). The value consists of in an oral literary tradition can also be used as a medium of self-humanization. It also seeks to encourage the creation of civilized human beings, humanizing humans, introducing the universality of the human nature, exercising emotional intelligence, and sharpening reasoning.

Regarding the spiritual context, the oral literature tradition can be seen as a religious teaching component that is able to provide awareness of the human interrelation nature to the God. The spiritual teachings in oral literary tradition can play a role as a planting of love and educate the child towards the embodiment of morals and the virtuous noble, therefore, be achieved peace and peace of the soul. In addition, the spiritual teachings in oral literature will create a more sensitive, intelligent, and responsive personality for the children dealing with and face social problems in the society. One of them is about understanding radicalism. The child character formed with the spiritual sublime teachings will have a more sensitive and intelligent soul to resist all events of violence and injustice in the society, unlike the radicalism acts.

In the Balinese tradition, the many oral literatures consist of the character education values that can be used as a powerful weapon in stemming the onslaught of the current radicalism attacks. An oral literature tradition in Balinese society can be divided into two types, they are tembang (poetry) and gancaran (prose). The literary tradition type oral popularly verbalized by the elders to their children is prose or often called satua (Balinese term). Masatua (telling Balinese story) tradition is a cultural heritage that has existed for a long time in Balinese society. Through this tradition that cultural transformation can be conveyed in a sustainable manner with a distinctive style. Masatua tradition in Bali has various functions, included for entertainment in filling a leisure time, conveying the various values of the life through the characters and dialogues unlike religious and moral messages in accordance with the ways of the characters convey the problem (Suastika, 2011: 1-2). There are several traditions of an oral literature (satua), the typical Balinese society that consists of the character education

Suarta, I. M. (2017). Revitalization of oral literature tradition of Balinese society based character values as deradicalism effort. International Journal of Social Sciences and Humanities, 1(3), 8-16. https://doi.org/10.29332/ijssh.v1n3.48 
value can be utilized as an alternative in counteracting the development rate of the radicalism, i.e. I Cicing Gudig, I Lacur, I Cerucuk Kuning, I Tuung Kuning, and I Angsa teken Empas. An oral literature (satua) above consists of the character education values about 18 fields, included discipline, hard work, responsibility, honest, democratic, social care, caring environment, tolerance, religious, reading, friendly/communicative, love peace, appreciate achievement, spirit of nationalism, love of the homeland, curiosity, independence, and creative.

In the oral literature (satua) I Cicing Gudig, there are Balinese spiritual values, i.e devotion or obedience to the Almighty God (Betara Durga/Dalem). In the I Cicing Gudig story, Betara Dalem gives a present repeatedly to I Cicing Gudig for transformation, from being an ordinary human, a caste, a kingdom, and a daughter of the king. Although in the story, I Cicing Gudig is depicted as a person who has a bad attitude in his behavior when given a gift, however, Betara Dalem always compassionate inquiry. It means that the God in Hinduism teachings will always be compassionate to the God devotees if he is always obedient and devoted to the religious teachings. I Cicing Gudig has applied the apara bhakti teachings to the God (Betara Dalem). Jendra (1998: 50) stated that there is two patterns of devotion to the Almighty God in Hindu teachings, namely para bhakti which means the high level of bhakti, and apara bhakti is bhakti which is low level and done in the hope of getting something from worship aspect that is the God. I Cicing Gudig story can also serve as a medium of self-reflection that the grace obtained from the Almighty God must be accounted for well, executed with sincerity, and earnest. Life in the world is full of struggle and nothing is instant, therefore, in order to run it requires consistency in self and surely hard work. Those are the qualities that I Cicing Gudig does not have everything, he always wants to live a good life by utilizing the grace of Betara Dalem, but he is also never satisfied with the life, he gets. Overall, the character of I Cicing Gudig in the story, described as an irresponsible person in the course of duty, never grateful, not fixed stance, like stealing, and lazy, however, His positive side is a devotee and obedient to the God/Betara Dalem.

Satua I Lacur in Balinese oral tradition is combined with the character education values included tolerance, friendship, social care, hard work, steadfast, and helpful. It teaches us to be steadfast, helpful, and hard work in order to achieve the desired goals, therefore, the life is better. Although, it became a very poor man, however, he was always grateful and never harbored envy and jealousy to others. Unlike, I Klaleng who was spiteful in I Lacur as a result, he falls down when climbing a tree and his leg broke. Although I Lacur feels humiliated with his greatness, he remains steadfast and helps I Klaleng who fell from a tree until unconscious. Thanks to the kindness, tenacity and hard work, I Lacur who once was poor then managed to become a rich man even appointed as Manca Agung/leader in Daha area. This is due to thank his ingenuity in the cure, he succeeded in healing Ida Raden Galuh son of the Supreme of the King, therefore, he was given a gift and appointed to be a leader in accordance with the vow delivered by the Supreme of the King. After that, he is no longer known by people named of $I$ Lacur but I Subagia. The name of I Subagia is obtained from the Supreme of the King for having contributed to Ida Raden Galuh life.

Satua I Tuung Kuning in Balinese oral tradition implies the value of the honest character education and love of peace. I Tuung Kuning is a representation of the women who experience discrimination from the hegemony of the patriarchal system in Balinese society. This tells a girl whose birth was not expected due to her own father wanted a son who would later become purusa in the family. I Tuung Kuning himself wanted to be killed by his father to vent his disappointment due he was not a boy but a girl. This can be stated as one of the discrimination forms faced by women in patriarchy. Budiman (1982: 1) stated that in a traditional environment living in a patriarchal culture, unlike Balinese society, the men have the highest position in performing their role as a person who has rights and duties as the head of household, while the women have naturally position to engage in the domestic domain. This position ultimately leads to gender inequality in Balinese society as told in I Tuung Kuning. However, thanks to his steadfastness, sincerity, and honesty, I Tuung Kuning finally got 
protection from an angel in khayangan (heaven), therefore, his father does now want to kill him anymore.

Satua I Cerucuk Kuning teaches us about the character education values unlike honesty, hard work, and responsibility of the attitude based on $\mathrm{Ni}$ Bawang character. The vice versa, $\mathrm{Ni}$ Kesuna's attitude gives us the reflection that the behavior as always lying in the duty and slandering is a bad habit and will definitely get hukum karma (karma law). The slanderous act is had by Ni Kesuna to Ni Bawang made her mother very angry that Ni Bawang was beaten and expelled from the house. Then Ni Bawang was gone to the middle of the forest and meet Crukcuk Kuning. Thanks to the honest attitude, hard work, always disciplined, and responsible possessed mastering Ni Bawang make Crukcuk Kuning become pity, therefore is given $\mathrm{Ni}$ Bawang various gold jewelry, diamonds, and gems. On the contrary, Ni Kesuna on her body was rewarded by I Crukcuk Kuning venomous beast due caught having a bad feeling that is not sincere until finally died in the middle of the bush.

\section{Revitalization of Oral Literary Tradition in Literature Learning Context}

The school has a change for children to socialize to the environment and character formation should be able to transmit the noble values of the regional culture, unlike ethics, morals, and courtesy, therefore, the children are not plagued by the negative globalism effects included a radicalism. In millennium-era, the children now are beginning to fade their locality mentality, they must be reinforced as soon as possible their locality mentality with reintroduction of the regional culture through an oral literature teaching. That is a way, awareness of children/learners will be local/local wisdom implies it will remain intact. Through learning oral literature in the schools, it is expected that the character education on it can be used to form the learner character become intelligent and the ethical human. Haryadi (1994) stated that an old/oral literature has nine benefits in the learner's life, (1) can be roled as the entertainment and educational media, (2) contents can foster loving, pride of nation and respect to the ancestors, (3) its contents can broaden the insights about the beliefs, customs, and civilizations of the nation (4) the performance can foster a sense of the unity and integrity, (5) the process of its creation fosters is creative, responsive, and dynamic soul, (6) an inspiration source for the creation of another art form, (7) the creation process is an example being diligent, professional, and humble work, (8) its performance exemplifies a compact and harmonious relationship, (9) the foreign influences on it illustrate the social and life-styles broad. In addition, Tjokrowinoto (in Haryadi, 1994) introduces the term "panca guna" to explain the benefits an oral literature, namely (1) strengthening religious education and character, (2) enhancing the love of homeland, (3) understanding the sacrifice of the hero nation, (4) increase the history knowledge, (5) introspective and entertaining.

An oral literary tradition has the potential to be interpreted as a medium for discovering Indonesian students' identity. The regional values in oral literature in Balinese society can serve as a reference for the introduction and deepen of the culture that becomes the plural Indonesian identity. An oral literature appreciation is one of the successful benchmarks of the literary teaching concerning the coaching of the learners' sensitivity to aesthetic phenomena and an expanding horizon of the human values. The aesthetic phenomenon appreciation will make learners more responsive to the culture as a result of the human creativity on its historicity. Oral literary learning in educational institutions has been able to become a guiding light that serves to guide human noble character.

Revitalizing of the oral literature at learning of the literature requires an active role of the teachers in doing creativity and innovation. The oral literature learning currently can still be stated to be stagnant. The children/learners feel less interested and less meaningful when getting in touch with literature. This is due the literature lessons still wallow in structural and theoretical issues. It takes a breakthrough and innovation to raise the children spirit in literature, especially an oral literature. The literature learning must begin to rise from the theoretical texts of the literary learning. A literary learning should begin to abandon the

Suarta, I. M. (2017). Revitalization of oral literature tradition of Balinese society based character values as deradicalism effort. International Journal of Social Sciences and Humanities, 1(3), 8-16. https://doi.org/10.29332/ijssh.v1n3.48 
tradition of crammed students with structural analysis and periodical memorization. It is especially oral literature should be oriented to the children/learners, i.e. the learner's appreciation of the literary works to be central. The teachers also must have a broad insight therefore, they are able to choose an oral literature based on the character education to children. The teachers do not only know but also have a lot of experience in the oral literature context. The experience can be used as a strategy to make the children fascinated on stories that teachers convey so that the children become motivated and gain new insights due to direct contact with the spoken oral literature is told. The child will experience a direct and authentic literary world, experiencing, and direct contact with the oral literature.

\section{Conclusion}

Revitalizing of the oral literature tradition in a life of the child is a necessity to respond radically to dialogue and absorption. It is in the family and the school environment can also be stated as an effort to prevent the radicalism basis through cultural approaches. Revitalizing of the oral literature tradition in a life, both family and educational institutions are the most realistic and strategic action taken to keep the children from the radicalism influence. In an ethnically ideological context, the oral literature tradition offers the lofty values of the local ethnic wisdom. An oral literary tradition is an expression of the ethnic cultural emotion and representation.

The schools as space for the children to socialize to the environment and character formation must be able to transmit the noble values of the regional culture, unlike ethics, morals, and courtesy, therefore, the children are not plagued by the negative globalism effects, including one understood is a radicalism. In millennium-era, the children now are beginning to fade mentality of their locality, they should be reinforced as soon as possible their locality mentality by re-introduction of the local culture through oral literary learning.

\section{Acknowledgement}

My deep and sincere gratitude were presented to God for having granted me the ability and the opportunity to complete this paper. As well as, I have much appreciated to my friends for their support, suggestion, contribution in finishing this research. I would like thank to Suryasa that has given me a good advisement. Last but not least, I dedicated my dreadful thank to my friend who those as editor in SS of International Journal. 


\section{References}

Eagling, C. M. (2011). Socio-political issues in women's fiction of the Reformasi (Doctoral dissertation, University of Tasmania).

Haryadi, D. (1994). A financial analysis of a teak forest managed for sustained production in West Java, Indonesia.

Kattsoff, L. O. (2004). Pengantar filsafat, penerjemah: Soejono Soemargono. Yogyakarta: Tiara Wacana.

Moehanto, B. (1987). Tuntunan Sekar Macapat. Pemalang: CV Mitra Utama.

Suastika, I. Made. 2011. Tradisi Sastra Lisan (Satua) di Bali. Kajian Bentuk, Fungsi, dan Makna. Denpasar: Pustaka Larasan.

Tilaar, H. A. R. (2000). Paradigma baru pendidikan nasional. Rineka Cipta.

Suarta, I. M. (2017). Revitalization of oral literature tradition of Balinese society based character values as deradicalism effort. International Journal of Social Sciences and Humanities, 1(3), 8-16. https://doi.org/10.29332/ijssh.v1n3.48 


\section{Biography of Author}

\begin{tabular}{|c|c|}
\hline & \\
\hline & 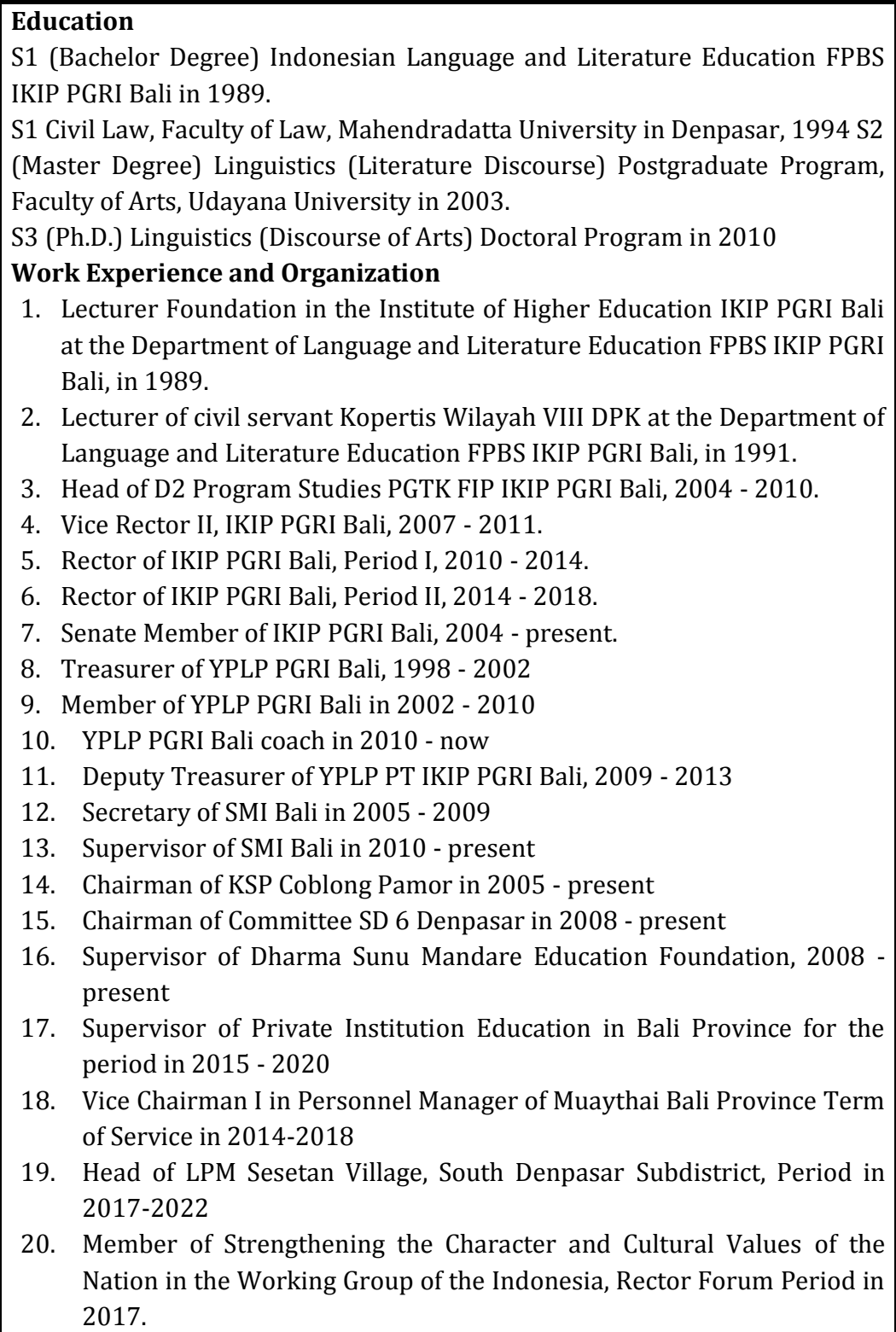 \\
\hline
\end{tabular}

